\title{
Effects of shading on leaf physiology and morphology in the 'Yinhong' grape plants
}

\author{
Tian $\mathrm{Qiu}^{1}$, Yueyan $\mathrm{Wu}^{2}$, ZiLi Shen ${ }^{3}$, Yanyan $\mathrm{Wu}^{4}$, Dan $\mathrm{Lu}^{5}$, Jingwen $\mathrm{He}^{6}$
}

\begin{abstract}
Shading is a practical measure to reduce the heat stress to grape trees in the summer. However, inappropriate shading will cause the reduction in leaf photosynthesis and consequently the retardation of growth for the plants or the loss of fruit yield and quality for the mature grape trees. In this study we have used 1-year-old 'YinHong' grape plants growing under different levels of shading, ranging from full sunlight $0 \%$ to $80 \%$ reduction, to investigate their growth, physiological and biochemical responses. The results show that shading rate $\leq 45 \%$ did not significantly affect grape growth. Shading over $45 \%$ reduction of the full sunlight, the growth of the grape plants were started to be inhibited. In addition, soluble protein content, the activities of catalase (CAT), peroxidase (POD) and superoxide dismutase (SOD), chlorophyll content, net photosynthetic rate $(\mathrm{Pn})$, stomatal conductance $(\mathrm{Gs})$, intercellular $\mathrm{CO}_{2}$ concentration $(\mathrm{Ci})$, transpiration rate ( $\mathrm{Tr}$ ), PSII photochemical efficiency (Fv/Fm), PSII potential activity ( $\mathrm{Fv} / \mathrm{Fo})$ and photochemical quenching (qP) were decreased, whereas free proline, malondialdehyde (MDA) content, the non-photochemical quenching coefficient ( $\mathrm{qN}$ ) and the ratio of the palisade/spongy tissue were gradually increased. In particular, significant changes in plant growth, photosynthetic and the other physiological and biochemical characteristics were observed under a strong shading. Index terms: grape, growth characteristics, shading.
\end{abstract}

\section{Efeitos de sombra sobre a fisiologia da folha e a morfologia nas plantas de uva "Yinhong"}

Corresponding author: wyy2000@zwu.edu.cn or 1186855629@qq.com;

Received: April 05, 2018 Accepted: June 12, 2018.

Copyright: All the contents of this journal, except where otherwise noted, is licensed under a Creative Commons Attribution License.

\section{(cc) $\mathbf{E Y}$}

Resumo- Sombreamento é uma medida prática para reduzir o estresse térmico para as árvores de uva no verão.No entanto, o sombreamento inadequado causará a redução da fotossíntese foliar e, consequentemente, o retardamento do crescimento das plantas ou a perda de rendimento e qualidade dos frutos das videiras maduras.Neste estudo, usamos plantas de uva 'YinHong' com 1 ano de idade crescendo sob diferentes níveis de sombreamento,variando de pleno sol $0 \%$ a $80 \%$ de redução, para investigar o seu crescimento, respostas fisiológicas e bioquímicas. Os resultados mostram que a taxa de sombreamento $\leq 45 \%$ não afetou significativamente o crescimento da uva.Sombreado com mais de $45 \%$ de redução da luz solar total, o crescimento das plantas de uva passou a ser inibido.Além do que, além do mais,conteúdo de proteína solúvel, as atividades de catalase (CAT), peroxidase (POD) e superóxido dismutase (SOD), conteúdo de clorofila, taxa fotossintética líquida (Pn), condutância estomática (Gs), concentração de CO2 intercelular (Ci), taxa de transpiração (Tr ), Eficiência fotoquímica de PSII (Fv / Fm), atividade potencial de PSII ( $\mathrm{Fv} / \mathrm{Fo}$ ) e quenching fotoquímico (qP) foram reduzidos,enquanto o teor de prolina livre, malondialdeído (MDA), o coeficiente de inibição não fotoquímica (qN) e a razão entre a paliçada / tecido esponjoso aumentaram gradualmente.Em particular, mudanças significativas no crescimento das plantas, fotossintéticas e outras características fisiológicas e bioquímicas foram observadas sob um forte sombreamento.

Termos de indexação: uva, características de crescimento, sombreamento. 


\section{Introduction}

The grape (Vitis vinifera) is perennial deciduous vine in the grape genus (Vitis L.) of Vitaceae, which is one of the oldest cultivated and most widely distributed trees. The Euramerican hybrid genus 'YingHong' was bred from a mutant plant and has become one of the main varieties of grape cultivation in Zhejiang Province. However, due to the limitations of the climate conditions and the conditions of cultivation facilities, especially in summer heat waves in combination with the strong sunlight could seriously affect the grape plants in terms of yield and quality (Sun et al. 2015; Fan et al. 2008; Chai et al.2012; Wang et al.2014 ). Therefore, shading is an essential practical measure to prevent the grape plants from such damages. However, long term and sever shading will result into light deficiency in plants and inhibit its growth and development (Ai et al.2004; An et al. 2012; Pietro et al. 2013; Hyo et al. 2014;Bertamini M, Nedunchezhian N, 2003; Bellasio C, Griffiths H 2014 ;Bertamini et al., 2006 ;Cuiet al.2015 ;He et al., 2011; Gao et al., 2005; Li 2012; Yi et al., 1999; Zhang 2005; Zhong 2003), which could be also revealed in the changes of many physiological and biochemical characteristics as well as the changes in leaf morphological features (He et al., 2011; Gao et al., 2005; Li 2012; Yi et al., 1999; Zhang 2005; Zhong 2003; Bertamini M, Nedunchezhian N 2003 ; Ivanova et al. 2008). Obviously, an optimal shading level is required to be determined for a specific plant. This is also the case for the grape plants.

In this work, we, therefore, setup five levels of shading $(0 \%, 25 \%, 45 \%, 60 \%$ and $80 \%$ reduction of the full sunlight) on one-year-old 'YingHong' grape plants to investigate the effects of shading on growth, photosynthesis and other physiological and biochemical processes. The data we obtained could guide the practice of shading in 'YingHong' grape cultivation in Zhejiang, China.

\section{Materials and methods}

\section{Plant materials and treatments}

One-year-old 'YinHong' grape plants were grown in a greenhouse for the grape cultivation experiments at Zhejiang Wanli University, Ningbo, China. These experiments were performed from May to August 2014.

On 5 May 2014, we planted 100 robust and uniformly growing 1-year-old 'YinHong' grape plants in earthen test pots $(29.5 \times 27.2 \times 17.0 \mathrm{~cm})$ filled with artificial compost (peat:rice chaff $=3: 1$ volume ratio). The composition of the compost was as follows: 49.3 $\mathrm{mg} \cdot \mathrm{kg}^{-1}$ organic matter, $41.1 \mathrm{mg} \cdot \mathrm{kg}^{-1}$ alkali solution with nitrogen, $8.2 \mathrm{mg} \cdot \mathrm{kg}^{-1}$ available phosphorus and 85.2 $\mathrm{mg} \cdot \mathrm{kg}^{-1}$ available potassium. The $\mathrm{pH}$ was maintained at
5.6. Before colonization, $1.5 \mathrm{~kg} \cdot \mathrm{m}^{-1}$ slow-release fertilizer $(\mathrm{N}: \mathrm{P}: \mathrm{K}=17: 17: 7)$ was applied to the compost at once. After colonization, 3 buds were left as stubs and 3 main buds were maintained. When the main shoot length reached $60 \mathrm{~cm}$, we left 2 vice tip in the top and 2 leaves in every vice tip.

Beginning on 15 May 2014, the plants were placed in a multi-span greenhouse with a shade net as a covering material. The test set included five treatments and each treatment was performed with 20 plants. These treatments included a control (CK), group I (one layer film shading with a shading rate of about $25 \%$ ), group II (two-layer film shading with a shading rate of about $45 \%$ ), group III (three-layer film shading with a shading rate of about $65 \%$ ) and group IV (four-layer film shading with a shading rate of about $80 \%$ ). If it rained, the top was covered with plastic film and the matrix relative humidity of all treatments was maintained at about $65 \%$. During the test, no additional fertilization was given.

Leaf samples were taken before shading and after shading treatments of $15 \mathrm{~d}, 30 \mathrm{~d}$ and $45 \mathrm{~d}$. For each treatment, 3 plants were randomly selected and 2 leaves per plant were collected to measure chlorophyll content, leaf gas exchange parameters and chlorophyll fluorescence parameters. Leaves were also collected to measure soluble protein content, MDA content, free proline content and the activity of CAT, POD and SOD.

After $45 \mathrm{~d}$ of shading treatment, 6 plants from each treatment were randomly selected to measure the index of root and leaf growth. Additionally, 3 trees were randomly selected from each treatment group and 3 leaves per plant were collected to measure the tissue microstructure of the leaves and the chloroplast ultrastructure of the palisade tissue.

\section{Analysis of chlorophyll content, leaf gas exchange parameters and chlorophyll fluorescence parameters}

The chlorophyll content was determined by a SPAD-502 + PLUS chlorophyll metre (KONICA MINOLTA, Japan). The leaf $\mathrm{Pn}, \mathrm{Tr}$, Gs and $\mathrm{Ci}$ was determined by a GFS-3000 portable photosynthesis analyzer (WALZ, Germany) during the hours of $10 \mathrm{AM}$ to $2 \mathrm{PM}$. The chlorophyll fluorescence parameters $\mathrm{Fv} / \mathrm{Fm}$, $\mathrm{Fv} / \mathrm{Fo}, \mathrm{ETR}, \mathrm{qP}$ and qN were determined by a JUNIORPAM chlorophyll fluorometer (WALZ, Germany) under shading treatment for $30 \mathrm{~min}$.

Analysis of the index of root and leaf growth, the tissue microstructure of leaves and the ultrastructure of the chloroplasts

The root length, diameter, surface area, volume and leaf area were counted using the LA-S versatile plant image analysis system in triplicate and we recorded the average of each set of measurements. 
Paraffin sections were made from both sides of the central main vein of the grape leaves $(4 \mathrm{~mm} \times 6$ $\mathrm{mm})$. They were fixed by FAA $[5 \mathrm{~mL}$ formalin $(38 \%$ formaldehyde solution), $5 \mathrm{~mL}$ glacial acetic acid and 90 $\mathrm{mL} 50 \%$ ethanol], , dehydrated by ethanol and a xylene series and embedded in paraffin wax in order to make the thickness of each transverse section $10 \mu \mathrm{m}$. Last used the saffron-solid green to dye. We measured the thickness of the epidermis, palisade tissue and spongy tissue at micrometre resolution under an OLYMPUS optical microscope and took photographs (Qin et al., 2012). From each treatment group, we selected 15 fields of view and took the average.

Material was taken from both sides of the central main vein of the grape leaves $(2 \mathrm{~mm} \times 4 \mathrm{~mm})$. It was first fixed by $2.5 \%$ glutaraldehyde and syringed by 0.1 mol. $\mathrm{L}^{-1}$ phosphate buffer ( $\mathrm{pH}$ 7.2). After that, the samples were fixed by $1 \%$ osmium tetraoxide, dehydrated by an ethanol gradient, acetone- processed for $20 \mathrm{~min}$ and embedded in Epon-812 epoxy. Uranyl acetate and lead citrate were used to dye 70-90 nm sections taken with an EM UC7 LEICA ultra-thin slicing machine (LEICA, Germany) after aggregated $24 \mathrm{~h}$ at $70 \square$. We photographed a typical field of view using a HITACHI-7650 transmission electron microscope (Meng et al., 2011). From each treatment group, we selected 15 fields to observe the ultrastructure of the chloroplasts.

\section{Analysis of protective enzymes and osmotic adjustment substances}

The soluble protein content was determined by Coomassie brilliant blue G-250 staining (Wang 2006a). The content of free proline was determined by the ninhydrin colorimetric method (Li 2009). The MDA content was determined by the thiobarbituric acid method (Zhang et al., 2004). The CAT, POD and SOD activities were measured by the UV absorption method (Wang 2006b), the guaiacol colorimetric method (Chang et al., 2007a) and the nitro-blue tetrazolium method (Chang et al., 2007b), respectively.

\section{Statistical analysis}

Original data grouping, drawing and significant difference analysis adopted excel software and SPSS 19.0 respectively.

\section{Results}

\section{Effects of shading on the growth characteristics of the 'YinHong' grape}

We examined the growth characteristics of the 'YinHong' grape plant under shading (Table 1). The data show that there was no significant change in the growth rates of the roots and leaves and all the indexes under $25 \%$ shading (Group I) comparing to no shading (CK).
This was also the case for $45 \%$ shading (Group II) except the leaf area of this group plants increased significantly. With increasing degree of shading, the light deficiency of the 'Yinhong' grape plants was becoming evident. The leaf blades became thin, a small number of leaves began to fall off and there were more macules on leaves. Under $65 \%$ shading (Group III) the leaf area had a little decrease but was comparable to the $\mathrm{CK}$, however, all of the other indicators were significantly lower than those of the control group $(\mathrm{P}<0.05)$. Interestingly, the leaves of $85 \%$ shading in group IV were significantly smaller than the no shading plants and became almost transparent and many had been shed, growth was severely inhibited and all indexes were significantly lower than those of the control group. Therefore, in summary less than $45 \%$ shading didn't affect the growth of 'YinHong' grape plants.

\section{Effects of shading on leaf morphology and the ultrastructure of the chloroplasts in 'YinHong' grape} leaves

We measured the cross-sectional thickness of leaf epidermis, palisade tissues and spongy tissues and used the thickness ratio of palisade over spongy tissues as an indicator of leaf morphology (Table 2). The palisade tissue was orderly arranged for a long column and the spongy tissue was arranged compactly which contained a large number of chloroplasts (Fig. 1A). Again the weak shading in group I and II didn't alter these ratios significantly indicating no effect on the leaf morphology (Fig. 1B and C). However, the severer shading in Group III and IV the palisade tissue cells began to accumulate large amounts of sediment, the shape became irregular and the palisade tissue and spongy tissue had reduced numbers of cells. The cell gap became larger and the irregular distribution of chloroplasts in cells became fewer (Fig. 1D and E), revealing a typical leaf morphology under light deficiency.

Meanwhile, we have also looked into the chloroplast ultrastructures affected by shading (Fig. 1F-J). Fig.1F shows that the cell vacuole membrane in palisade tissue was integrated, the chloroplasts were crowded at the edge of the cell by the vacuole and became flattened. The chloroplast stroma lamellae and the grana lamellae were similar to a parallel arrangement with the major axis of the chloroplast. Meanwhile, there were many grana lamellae, thylakoids were arranged close together in an orderly manner, the stroma were dense and contained starch grains and the osmium particles were relatively small and few (Fig. 1F). In corresponding to the leaf morphology, the chloroplast ultrastructure was not significantly altered under a weak shading in Group I (Fig. 1G). This was also the case for Group II under $45 \%$ shading (Fig. 1H), but the chloroplasts swelled and contained starch grains and the osmium particles became large and increased in number (Fig. 1H). With increasing shading severity, the 
chloroplasts became obviously enlarged, the structure of lamellae loosen, the stroma thinned and contained starch grains and the osmium particles became large and increased in number (Fig. 1I and J).

Effects of shading on the characteristics of photosynthesis in 'YinHong' grape leaves

Firstly we examined the changes of chlorophyll content under shadings. In the weak shadings (Groups I and II), the relative chlorophyll content was similar to that of the control group, in that it first increased and was then maintained at a stable state (Fig. 2B). Compared with the control, the relative chlorophyll content increased by $8.7 \%$ and $9.7 \%$ for groups I and II, respectively $(\mathrm{P}>0.05)$. However, under the severer shading (Group III and IV) the relative chlorophyll content decreased with increasing treatment time and at the end of the test, it decreased by $28.5 \%$ and $40.6 \%$ for groups III and IV, respectively, which were significantly lower than that of the control group $(\mathrm{P}<0.05)$.

Then we measured the gas exchange parameters of grape leaves with different shading treatment. For groups I and II, the gas exchange parameters were similar to those of the control group (Fig. 2). Pn and Tr decreased by $2.8 \%$ and $2.1 \%$ for group I and $9.8 \%$ and $8.3 \%$ for group II, respectively. $\mathrm{Ci}$ and Gs increased by $4.3 \%$ and $4.1 \%$ for group I and $7.5 \%$ and $7.8 \%$ for group II, respectively, which also were not significant $(\mathrm{P}>0.05)$. With increasing shading intensity, photosynthetic characteristics also decreased significantly. For groups III and IV, Pn, Tr, Ci and Gs decreased by $43.8 \%, 38.6 \%, 31.0 \%$ and $32.7 \%$ for group III and $52.7 \%, 51.0 \%, 35.3 \%$ and $49.0 \%$ group IV, respectively, which were significantly lower than those of the control group $(\mathrm{P}<0.05)$.

We also measured the chlorophyll fluorescence parameters in leaves during the time courses of shading. Fv/Fm, Fv/Fo, qP and ETR all declined to varying degrees, whereas qN increased (Fig. 3). The Fv/Fm, Fv/Fo, qP and ETR values for groups I and II decreased by $1.3 \%$, $1.1 \%, 2.3 \%$ and $1.9 \%$ and $7.3 \%, 11.0 \%, 9.9 \%$ and $6.8 \%$, respectively. qN on the other hand increased by $4.7 \%$ and $7.7 \%$ for groups I and II, respectively, which were not significant $(\mathrm{P}>0.05)$. For groups III and IV, Fv/Fm, Fv/ Fo, qP and ETR respectively decreased by $21.5 \%, 56.7 \%$, $28.7 \%$ and $39.9 \%$ and $26.5 \%, 63.4 \%, 36.6 \%$ and $68.4 \%$, which were significantly lower than those of the control group $(\mathrm{P}<0.05)$. However, $\mathrm{qN}$ increased by $31.6 \%$ and $53.8 \%$ for groups III and IV, respectively, which was significantly higher than that of the control $(\mathrm{P}<0.05)$.

Effects of shading on the biochemical features

\section{of 'YinHong' grape leaves}

We next checked the biochemical changes, firstly the total protein levels under shading. Figure 4A shows that there was no significant change in the soluble protein content of all shading treatments after $15 \mathrm{~d}$. However after
$15 \mathrm{~d}$, weak shading $(25 \%)$ had increased the soluble protein content in leaves, while all other severer shading $(45 \%$, $65 \%$ and $85 \%$ ) caused a significant decrease in the soluble protein levels (Fig. 4A). In contrast, the free amino acid proline content was increased with the increasing levels of shading (Fig.4C), indicating a decrease in protein de novo synthesis.

During the period of shading treatments, the MDA in leaves was increasing with the development of grape plants under no shading and a weak shading (25\% GroupI), but the weak shading has still inhibited such an increase. However, the other severer $45 \%$ to $85 \%$ shadings have completely abolished such an increase in MDA (Fig.4B).

In groups I and II, the CAT, POD and SOD activities first increased and were then maintained at a stable state (Fig.4), which then decreased by $2.7 \%, 2.2 \%$ and $1.3 \%$ for CAT, POD and SOD, respectively, for group II and by $11.0 \%, 9.2 \%$ and $11.0 \%$, respectively, for group III. These changes were not significant $(\mathrm{P}>0.05)$. For groups III and IV, the CAT, POD and SOD activities first increased to a maximum at $15 \mathrm{~d}$ of stress and then decreased sharply. Compared with the control group, these activities then decreased by $26.5 \%, 27.0 \%, 26.6 \%$ and $45.2 \%, 37.8 \%$, $49.4 \%$, respectively, for groups III and IV, which were significantly lower than those of the control group $(\mathrm{P}<$ $0.05)$.

\section{Discussion}

In this study, we have investigated how shading affected the growth of the 'YinHong' grape plants in the summer in Ningbo, China. Our results show that weak shading under $45 \%$ reduction of the full light exposure didn't affect the growth of the grape plants, on contrary had some beneficiary effects on them as shown in an increased protein content in the leaves (Fig.4A). This might be also suggested that the beneficiary effects of shading can be resulted from the reduction of high leaf temperature under the summer heat waves, though the leaf temperatures have not been measured unfortunately in this study, since high temperature would adversely affect many physiological and biochemical processes $(\mathrm{Fu}, \mathrm{T}$. et al.2014; Liu, F. F. 2010; LI Xiao-Ling, LUO Ling-Ling, HUA Zhi-Rui.2018). Therefore, further experiments are required to study the combined effects of light with temperature in future.

Our results also show that the severer shading (more than $45 \%$ reduction of full light exposure) had seriously inhibited the growth of grape plantss, exhibiting the leaf phenotypes of light deficiency as reported elsewhere from thinner broaden leaves under mild shading(Liu et al., 2012) to smaller leaves under extreme shading ( $\mathrm{Li}$ 2012). Light deficiency caused by severer shading was also revealed in those changes in the leaf physiological characteristics (Fig.2) and biochemical features (Fig.3) 
as well as reflected in the ultrastructures of chloroplasts in leaves (Fig.4). The deterioration of photosynthetic apparatus was also obvious as shown these changes in chloroflurescence, especially the decrease in qQ while the increase in $\mathrm{qN}$ (Fig.3). Fv/Fo represents the activity of PSII and $\mathrm{Fv} / \mathrm{FM}$ represents light energy conversion efficiency in the PSII reaction centre, which is a 'probe' index to reflect the degree of environmental stress. ETR represents photochemical electron transmission efficiency, qP reflects the portion of the PSII antenna pigments which capture light energy for photochemical electron transmission and qN reflects the part of the PSII antenna pigments which absorb light energy and dissipate in the form of heat energy (Yang et al., 2010). In this study, the decline of $\mathrm{Fv} / \mathrm{Fo}$ and $\mathrm{Fv} / \mathrm{Fm}$ show that the potential activity centre of PSII was damaged, the light reaction was inhibited, the leaf light energy utilization rate was reduced and the photosynthetic electron transfer process was hindered, thereby affecting $\mathrm{CO}_{2}$ fixation and assimilation during the dark reaction phase under weak light stress. The decline of qP and ETR show that the portion and efficiency of the PSII antenna pigments capturing light energy for photochemical electron transfer were decreased. $\mathrm{qN}$ increased significantly, which indicates that the portion of the PSII antenna pigments which absorb light energy and dissipate in the form of heat energy was increased and part of the photochemical electron transfer decreased. This coincided with a decreased qP(Fig.3)

Interestingly, the severer shading had also caused the reduction of protective enzyme activities (Fig.4D-F), indicating the loss of stress tolerance of plants (Wu et al., 2013; Yu et al., 2005). Again this effect requires a further study.

In this study the shading effects have been investigated only on the young grape plants, it is not easy to extrapolate such effects on to the fruiting grape trees, which would be much complicated as the presence of fruit production (Pietro et al. 2013) or in strawberry (Hyo et al. 2014). Thus it is much more important to study the shading effects on the adult grape trees, especially on these processes such as the flowering, pollen fertilization, fruit setting and development, finally the fruit quality. Certainly, these data if obtained will guide practically and improve greatly the grape fruit production in this area.

Table 1. Effects of shading on the growth characteristics of 'YinHong' grape

\begin{tabular}{|c|c|c|c|c|c|c|}
\hline \multirow{2}{*}{ Treatment } & \multicolumn{3}{|c|}{ Root system } & \multirow[b]{2}{*}{$\begin{array}{l}\text { Volume } \\
\left(\mathrm{cm}^{3}\right)\end{array}$} & \multirow[b]{2}{*}{$\begin{array}{l}\text { Leaf area } \\
\left(\mathrm{cm}^{2}\right)\end{array}$} & \multirow{2}{*}{$\begin{array}{l}\text { Leaves } \\
\text { Morphological } \\
\text { characteristics }\end{array}$} \\
\hline & Length $(\mathrm{cm})$ & $\begin{array}{c}\text { Average } \\
\text { diameter }(\mathrm{mm})\end{array}$ & $\begin{array}{c}\text { Surface area } \\
\left(\mathrm{cm}^{2}\right)\end{array}$ & & & \\
\hline CK & $1860.4 \pm 4.3 \mathrm{a}$ & $1.01 \pm 0.03 \mathrm{a}$ & $621.2 \pm 4.4 \mathrm{a}$ & $14.2 \pm 0.5 \mathrm{a}$ & $490.2 \pm 3.2 b$ & normal green \\
\hline I & $1843.2 \pm 4.3 \mathrm{a}$ & $0.99 \pm 0.02 \mathrm{a}$ & $632.3 \pm 5.2 \mathrm{a}$ & $14.3 \pm 0.5 \mathrm{a}$ & $485.0 \pm 3.6 b$ & normal green \\
\hline II & $1803.6 \pm 4.4 \mathrm{ab}$ & $0.93 \pm 0.05 \mathrm{ab}$ & $557.3 \pm 4.8 \mathrm{ab}$ & $12.5 \pm 0.6 \mathrm{ab}$ & $565.6 \pm 3.3 \mathrm{a}$ & $\begin{array}{c}\text { ordinary } \\
\text { litter macules, thin }\end{array}$ \\
\hline III & $1462.1 \pm 3.6 \mathrm{~b}$ & $0.76 \pm 0.05 b$ & $428.2 \pm 3.7 \mathrm{~b}$ & $8.4 \pm 0.4 b$ & $523.8 \pm 2.9 \mathrm{ab}$ & $\begin{array}{l}\text { litter shedding } \\
\text { more macules, thin }\end{array}$ \\
\hline IV & $953.2 \pm 3.7 \mathrm{c}$ & $0.61 \pm 0.04 \mathrm{c}$ & $315.2 \pm 3.1 \mathrm{c}$ & $6.4 \pm 0.4 \mathrm{c}$ & $365.2 \pm 3.2 \mathrm{c}$ & $\begin{array}{l}\text { mass shedding } \\
\text { large macules, thin }\end{array}$ \\
\hline
\end{tabular}

*Treatments included a control of no shading (CK), group I (one layer film shading with a shading rate of about $25 \%$ ), group II (two-layer film shading with a shading rate of about $45 \%$ ), group III (three-layer film shading with a shading rate of about $65 \%$ ) and group IV (four-layer film shading with a shading rate of about $80 \%)$. Note: Different letters in a column indicate a significant difference $(\mathrm{P}<0.05)$.

Table 2. Changes in the anatomical structure of 'YinHong' grape leaves under shading $(\mathrm{n}=15)$

\begin{tabular}{ccccc}
\hline Treatments & $\begin{array}{c}\text { Leaf epidermis } \\
\text { thickness }(\mu \mathrm{m})\end{array}$ & $\begin{array}{c}\text { Palisade } \\
\text { tissue thickness }(\mu \mathrm{m})\end{array}$ & $\begin{array}{c}\text { Spongy tissue } \\
\text { thickness }(\mu \mathrm{m})\end{array}$ & $\begin{array}{c}\text { Palisade tissue/ } \\
\text { Spongy tissue }\end{array}$ \\
\hline CK & $15.5 \pm 1.0 \mathrm{a}$ & $33.2 \pm 1.3 \mathrm{a}$ & $45.2 \pm 2.2 \mathrm{a}$ & $0.73 \pm 0.04 \mathrm{c}$ \\
I & $15.6 \pm 0.8 \mathrm{a}$ & $33.7 \pm 1.2 \mathrm{a}$ & $44.0 \pm 1.6 \mathrm{a}$ & $0.77 \pm 0.06 \mathrm{~b} \mathrm{c}$ \\
II & $14.9 \pm 0.9 \mathrm{ab}$ & $32.5 \pm 1.5 \mathrm{ab}$ & $40.6 \pm 2.5 \mathrm{ab}$ & $0.80 \pm 0.08 \mathrm{~b}$ \\
III & $14.1 \pm 1.1 \mathrm{~b}$ & $28.6 \pm 1.2 \mathrm{~b}$ & $30.8 \pm 1.8 \mathrm{~b}$ & $0.93 \pm 0.10 \mathrm{ab}$ \\
IV & $12.2 \pm 1.3 \mathrm{c}$ & $24.2 \pm 1.2 \mathrm{c}$ & $24.7 \pm 2.3 \mathrm{c}$ & $0.98 \pm 0.07 \mathrm{a}$ \\
\hline
\end{tabular}

*Treatments included a control of no shading (CK), group I (one layer film shading with a shading rate of about 25\%), group II (two-layer film shading with a shading rate of about $45 \%$ ), group III (three-layer film shading with a shading rate of about $65 \%$ ) and group IV (four-layer film shading with a shading rate of about $80 \%)$. Note: Different letters in a column indicate a significant difference $(\mathrm{P}<0.05)$. 

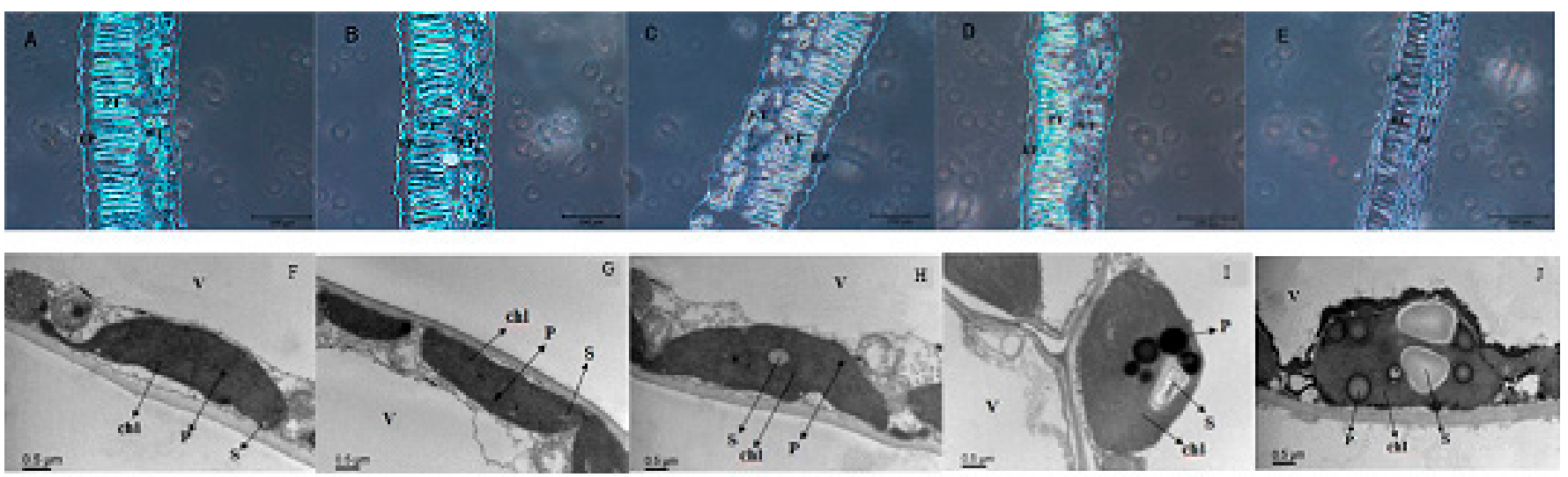

Figure 1. A cross-section of 'YinHong' grape leaves under shading and cell ultrastructure in the palisade tissues. Upper row A, B, C, D and E show cross-sections of 'YinHong' grape leaves under normal conditions of no shading, 25\%, 45\%, 65\% and 80\% shading, respectively. (Bar $=100 \mu \mathrm{m}$ ). EP: Epidermal cell; PT: Palisade tissue; ST: Spongy tissue. Bottom row F, G,H, I and J show cell ultrastructure in the palisade tissue of 'YinHong' grape leaves under normal conditions of no shading, 25\%, 45\%, 65\% and $80 \%$ shading, respectively. (Bar $=0.5 \mu \mathrm{m}$ ). Chl: chloroplast; V: vacuole; S: starch grain; P: plastoglobules

\section{A. Pn}

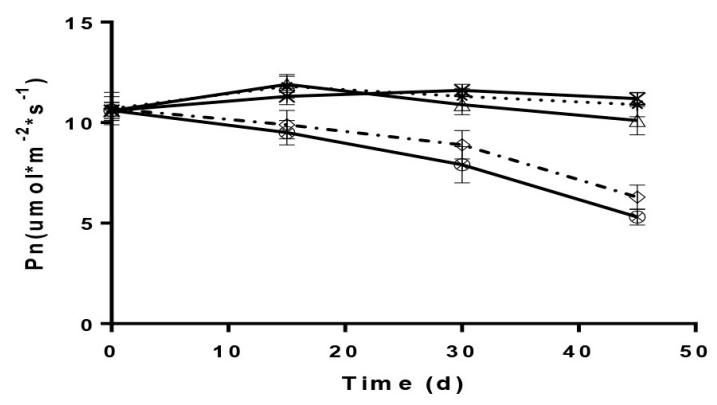

C. Tr

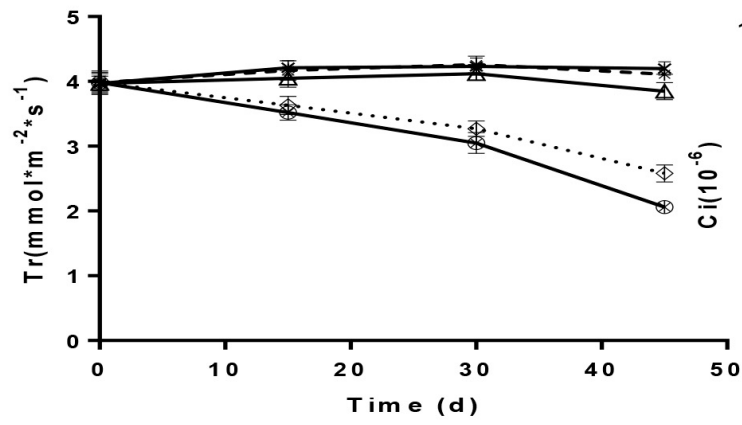

E. G s

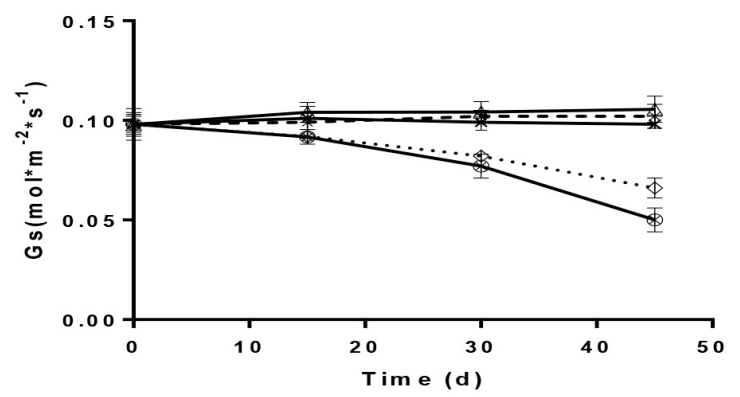

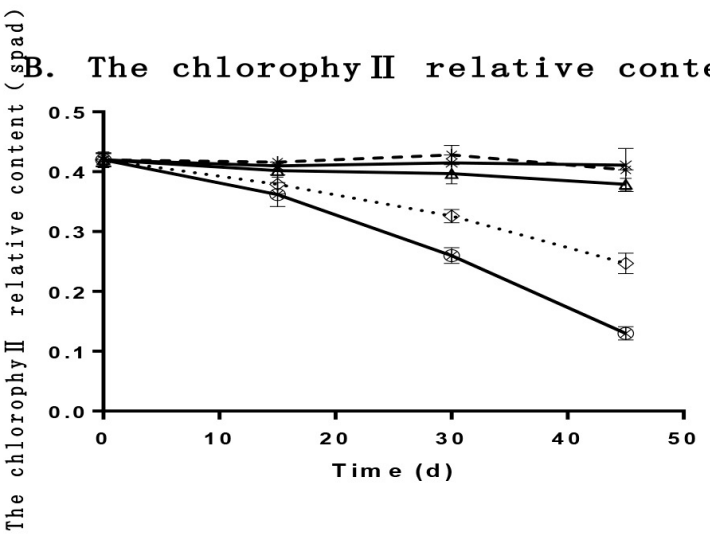

$\stackrel{\text { }}{\omega}$ B. The chlorophy II relative content

D. C i

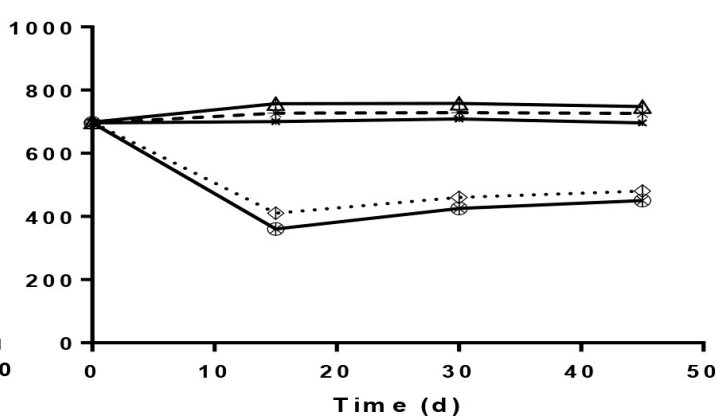

* ck

-*. treatment I

$\triangle$ treatment II

. $\leftrightarrow$. treatment III

- treatment IV

Figure 2 Effects of shading on photosynthetic features of 'YinHong' grape leaves. A. Pn; B. chlorophyll relative content; C. Tr; D. Ci; E. Gs. Treatments included a control of no shading (CK), group I (one layer film shading with a shading rate of about $25 \%$ ), group II (two-layer film shading with a shading rate of about $45 \%$ ), group III (three-layer film shading with a shading rate of about $65 \%$ ) and group IV (four-layer film shading with a shading rate of about $80 \%$ ). 


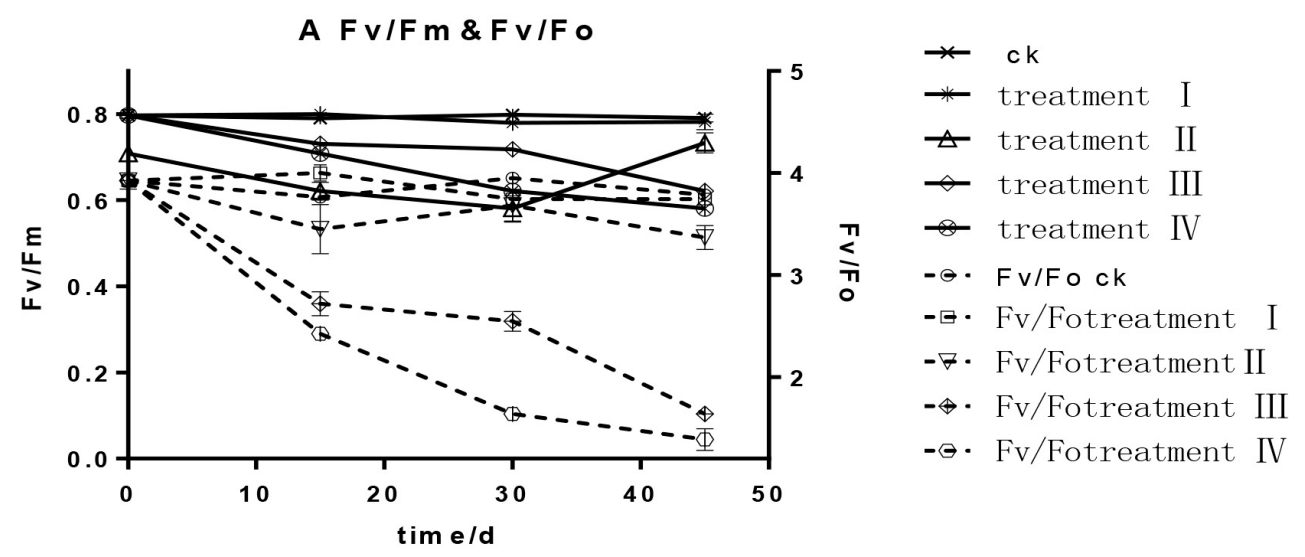

B $q P$

$C q N$
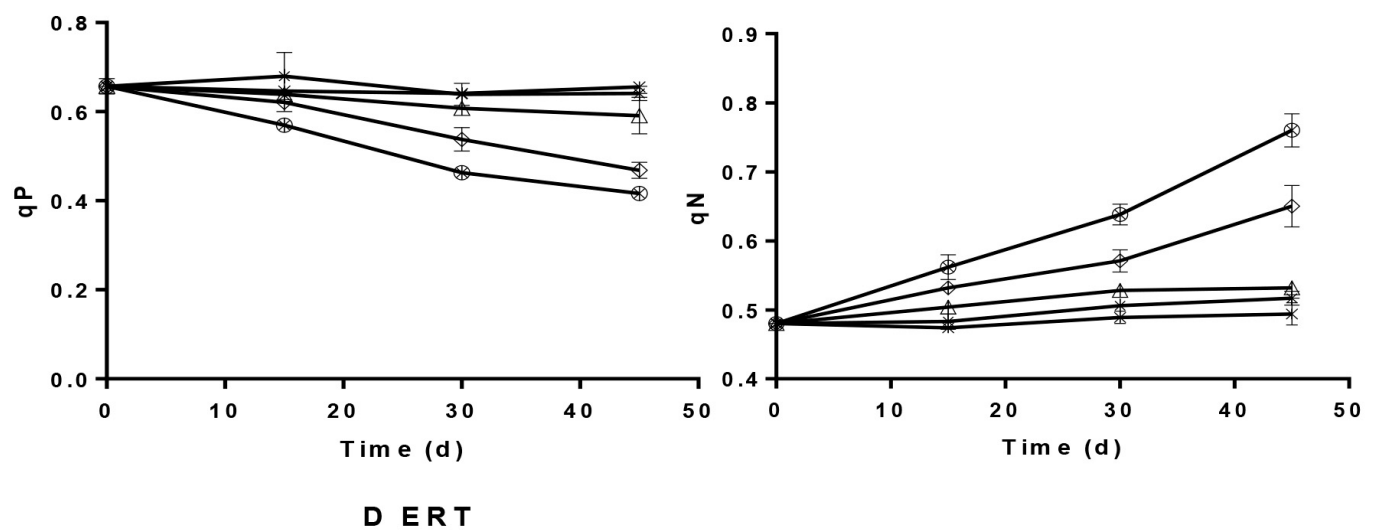

D ERT

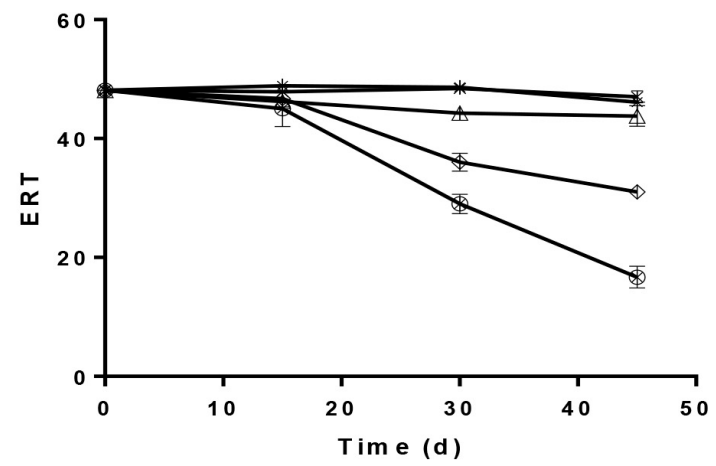

Figure 3. Effects of shading on chlorophyll fluorescence parameters of 'YinHong' grape leaves. A. Fv/Fm; B. qP; C. qN; D. ERT. Treatments included a control of no shading (CK), group I (one layer film shading with a shading rate of about 25\%), group II (two-layer film shading with a shading rate of about $45 \%$ ), group III (three-layer film shading with a shading rate of about $65 \%$ ) 

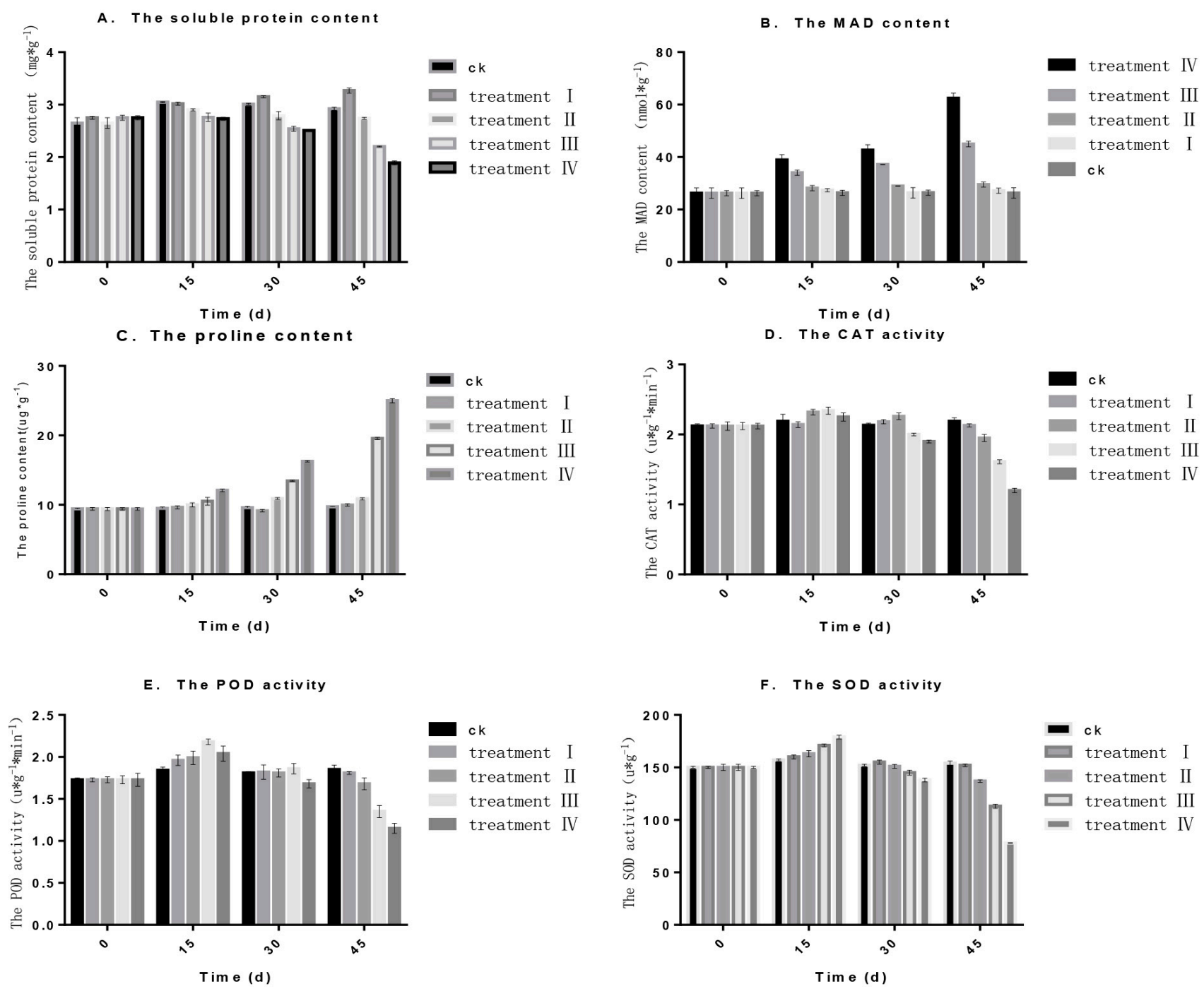

and group IV (four-layer film shading with a shading rate of about $80 \%$ ).

Figure 4. Effects of shading on biochemical features of 'YinHong' grape leaves. A. the soluable protein content; B. MDA content ; C. free proline content ; D. CAT activity; E. POD activity; F. SOD activity. Treatments included a control of no shading (CK),

\section{Conclusions}

Our results show that a weak shading less than $45 \%$ of full exposure in the summer didn't significantly affect the growth of grape plants and leaf gas exchange parameters, chlorophyll fluorescence parameters, tissue cell microstructure, chloroplast ultrastructure and other physiology-biochemistry indexes. The $25 \%$ shading did even slightly improve the growth and development of grape plants, implying that the shading can prevent the damage from the heat shocking of high temperature to grape plants in the summer. The grape plant growth was obviously inhibited under severer shading, revealing those leaf features under light deficiency by all the biochemical and physiological data obtained in this work. Therefore, we may conclude that in Zhejiang area in the summer the optimal shading for grape seedlings is around $25 \%$ to $45 \%$ shading of full light exposure.

\section{Acknowledgements}

We acknowledge joint funding by Ningbo Municipal Agriculture Major Program (2015C110016), Zhejiang Provincial Science and Technology Project (2017C34005). 


\section{References}

AI, X.; GUO, Y.; MA, X.; XING, Y.; ZHONGGUO, N.K. Photosynthetic characteristics and ultrstructure of chloroplast of cucumber under low light intensity in solar greenhouse. Scientia Agricultura Sinica, Beijing, v.37, n.2, p.268-273, 2004.

AN, C.X. et al. Photosynthetic characteristics of shading Melon leaves. Acta Botanica Boreali-Occidentalia Sinica, Yangling, v.32, p.342-347,2012.

BELLASIO, C.; GRIFFITHS, H. Acclimation of $\mathrm{C} 4$ metabolism to low light in mature maize leaves could limit energetic losses during progressive shading in a crop canopy. Journal of Experimental Botnay, Oxford, v.65, p.3725-3736, 2014.

BERTAMINI, M.; NEDUNCHEZHIAN, N. Photoinhibition of photosynthesis in mature and young leaves of grapevine (Vitis vinifera L.). Plant Science, Amsterdam, v.164, p.635-644, 2003.

BERTAMINI, M; MUTHUCHELIAN, K.; NEDUNCHEZHIAN, N.N. Shade effect alters leaf pigments and photosynthetic responses in Norway spruce (Picea abies L.) grown under field conditions. Photosynthetica, Praha, v.44, p.227-234, 2006.

CHAI, S.F. et al. Effect of strong light stress on the growth-biomass and chlorophyll fluorescence parameters in seedlings of endangered plant camellia nitidissima. Bulletin of Botanical Research, Harbin, v.32, n.2, p.159164, 2012.

CHANG, F.C. et al. Plant physiology experiment. Nanjing: Nanjing Normal University Press, 2007a. p.169-170.

CHANG, F.C. et al. Plant physiology experiment. Nanjing: Nanjing Normal University Press, 2007b. p.158-159.

CUI, H.; CAMBERATO, J.; JIN, L.; ZHANG, J. Effects of shading on spike differentiation and grain yield formation of summer maize in the field. International Journal of Biometeorology, Amsterdam, v.9, n.9, p.1189-1120,2015.

FAN, H. H.. GUAN, L.; LI, T.; CAI, Y. Effects of exogenous Nitric oxide on the chlorophyll fluorescence and antioxidant system of dendrobium huoshanense under high light stress. Journal of Horticulture, London, v.35, n. 8, p.1215-1220, 2008.
FU, T.; WU, Y.; LUI, R.; RAO, H. Physiological and biochemical responses of grape Yinhong seedlings to short-term weak-light stress. Jiangsu Journal of Agricultural Sciences, Yanzhou, v.30, p.405-410,2014.

GAO, S.S., et al. The effects of continuous shading on the growth and chlorophyll fluorescence parameters in tomato seedlings. Liaoning Agricultural Sciences, Shenyang, v.3, p.31-32, 2005.

HE, X.Y. et al. Research progress on effects of lowlight stress on plant growth. Nonwood Forest Research, Zhuzhou, v.29, p.131-136, 2011.

HYO, G.C.; BYOUNG, Y.M.; NAM, J.K.; JOON, K.K.; KHOSHIMKHUJAEV, B.; KYOUNG, S.P.; SUN, Y.L. Yield loss and quality degradation of strawberry fruits cultivated under the deficient insolation conditions by shading. Horticulture Environment Biotechnology, New York, v.55, n.4, p.263-270, 2014.

IVANOVA, L.A.; IVANOV, L.A.; RONZHIN, D.A.; P'YANKOV, V.I. Shading-induced changes in the leaf mesophyll of plants of different functional types. Russian Journal of Plant Physiology, Moscow, v.55, n.2, p.211219,2008.

LI, J. Effects of chilling and low light on vegetative and physiological parameters of melon seedlings. Journal of Henan Agricultural Sciences, Zhengzhou, v.41, p.106109, 2012.

LI, L. Experimental instruction of plant physiology module. Beijing: Science Press, 2009. p.86-88.

LI, Q. Effects of low temperature and low light stress on physiological characteristics of melon seedlings. Hubei: Huazhong Agricultural University, 2012.

LI, X.L.; LI, X,L.; LUO L.L.; HUA, Z.R. Physiological and biochemical responses of rhododendron lapponicumto heat stress. Northwest Journal of Agriculture, Yangling, v.27, n.2, p.253-259, 2018. (1) (mudar p. linha de LI Xiao-Ling, LUO Ling-Ling, HUA Zhi-Rui p.8 linha 19 para LI et al. (2018)).

LIU, F.F. Effect of low temprature stress on photosynthesis and chlorophyll fluorescence and physiological characteristics on cotton seedlings. Shihezi: Shihezi University, 2010. 
LIU, H.M. et al. Photosynthetic adaptability of the resistance ability to weak light of 2 species Spiraea L. Acta Ecologica Sinica, Beijing, v.32, p.7519-7531, 2012.

MENG, F.J. et al. The ultrastructure of chloroplast in mesophyll cell on two robinias under $\mathrm{NaCl}$ and $\mathrm{Na} 2 \mathrm{SO} 4$ stress. Acta Ecologica Sinica, Beijing, v.31, p.734-741, 2011.

PIETRO, S.; PISCIOTTA, A.; PATTI, D.; TAMBORRA, P.; LORENZOM, R.D.; BARBAGALHO, M.G. Effect of artificial shading on the tannin accumulation and aromatic composition of the Grillo cultivar (Vitis vinifera L.). BMC Plant Biology, London, v.13, p.175, 2013.

QIN, L.; KANG, W.H.; QI, Y.L.; CAI, A.J. Effects of salt stress on mesophyll cell structures and photosynthetic characteristics in leaves of wine grape (Vitis spp.). Scientia Agricultura Sinica, Beijing, v.45, p.42334241,2012 .

SUN, K.X. et al. Effects of exogenous calcium on photosynthetic chracteristics of sweet pepper (Capsicum fructescens 1.) seedlings. Journal of Plant Physiology, Jena, v.51, n.3, p.280-286, 2015.

WANG, X.K. Principles and techniques of plant physiology and biochemistry experiment. Beijing: Higher Education Press, 2006b. p.169-170.

WANG, X.K. Principles and techniques of plant physiology and biochemistry experiment. Beijing: Higher Education Press, 2006a. p.190-191.

WANG, Y.X.; ZHANG, H.; HOU, P.; SU, X.; ZHAO, P.; ZHAO, H.; LUI, S. Foliar-applied salicylic acid alleviates heat and high light stress induced photoinhibition in wheat (Triticum aestivum ) during the grain filling stage by modulating the psbA gene transcription and antioxidant defense. Plant Growth Regulation, Ames, v.73, n.3, p.289-297, 2014.
WU, Y.Y. et al. Effects of light stress on the physiological, biochemical characteristics and growth of vessel seedling. Plant Physiology Journal, Müchen, v.49, p.469-476, 2013.

YANG, S.P.; WEI, C.; LIANG, Y. Effects of $\mathrm{NaCl}$ stress on the characteristics of photosynthesis and chlorophyll fluorescence at seedlings stage in different sea island cottonenotypes. Scientia Agricultura Sinica, |Beijing, v.43, p.1585-1593, 2010.

YI, J.X.; CHEN, J.H. The effects of low light stress on the plant morphology and two physiological indexes in eggplant. Jiangsu Agricultural Sciences, Nanjing, v.23, n.6, p.62-65,1999.

YU, J.H.; ZHANG, G.; FENG, Z.; LI, X. Effects of low temperature and weak light on anti-oxidative enzyme activities and plasm.-membrane permeability of pepper seedlings. Acta Botanica Boreali-Occidentalia Sinica, Xian, v.25, p.2478-2483,2005.

ZHANG, G. B. The effects of low temperature and poor light on the growth physiological characteristics of photosynthesis in pepper seedlings (Capsicum annuum L.). Gansu Agricultural University, Beinjing, v.37, p.339, 2005.

ZHANG, Z.A. et al. Experimental instruction of plant physiology. Beijing: China Agricultural Science and Technology Press, 2004. p.138-139.

ZHONG, P.F. The effects of low light intensity on photosynthetic properties and growth and development of muskkmelon (Cucumis melo L.). Gansu Agricultural University, Beinjing, v.36, p.1693-1696, 2003. 